\section{White House axes risk-assessment bulletin}

The White House has withdrawn a controversial bulletin that would have sought to standardize the way in which US government departments use science to assess risks.

The bulletin had been fiercely criticized as an underhand attempt to weaken regulatory agencies such as the Environmental Protection Agency (see Nature 442, $242-$ 243 ; 2006). Having been asked by the White House to review the document, the National Academy of Sciences last autumn called for its complete withdrawal.

But earlier this year, senior officials at the White House Office of Management and Budget $(\mathrm{OMB})$ said that the bulletin was still in play (see Nature 448,$624 ; 2007$ ). With senators pressing for its withdrawal, however, the OMB announced on 19 September that the bulletin is no more, and instead issued a memo updating its previous, 1995 advice on scientific risk assessment.

\section{Lack of inspection raises concerns over drug trials}

Incomplete data, lack of coordination and poor follow-up are hampering the overseeing of clinical trials by the US Food and Drug Administration (FDA), says a government report.

The 28 September report - from the inspector-general's office in the department that oversees the FDA - found that the agency has no comprehensive database of the clinical trials it requires of companies developing new drugs and devices. On the basis of information in a National Institutes of Health trials registry, the report said that the FDA probably inspected fewer than $1 \%$ of all such trial sites between 2000 and 2005.

In addition, some $75 \%$ of FDA inspections were focused on verifying the accuracy of data in previously completed trials, rather than on protecting human subjects in active trials. The FDA responded that its most important role in protecting human subjects takes place before clinical trials begin, when it reviews company protocols.

\section{Climate sceptic quits over 'lack of academic freedom'}

Patrick Michaels, one of the most controversial sceptics on global warming, retired from his post as state climatologist for Virginia earlier this summer, citing concerns about academic freedom.

Michaels, an environmental scientist at the University of Virginia in Charlottesville, which co-hosts the state's climatology office, has been criticized for playing down the risks of global warming. As a result, Virginia's Democratic governor, Timothy Kaine, last year asked him not to use the title of state climatologist.

After news of his resignation broke last week, Michaels released a statement saying it was "impossible to maintain academic freedom" because his budget - and his salary - had become politicized. Joseph Zieman, who chairs the university's environmental sciences department, counters that it was the consulting Michaels did for energy companies that got him into trouble. The University of Virginia has appointed Jerry Stenger to head the climatology office, although his official title is research coordinator.

\section{Dawn mission to asteroid belt has lift-off at last}

After surviving one cancellation and more than a year's additional delay, NASA's Dawn probe was launched into space on 27 September riding atop a Delta II rocket. The mission to the asteroid belt between Mars and Jupiter had been held up by problems including crane malfunctions and the slow

\title{
See-through frog offers inside information
}

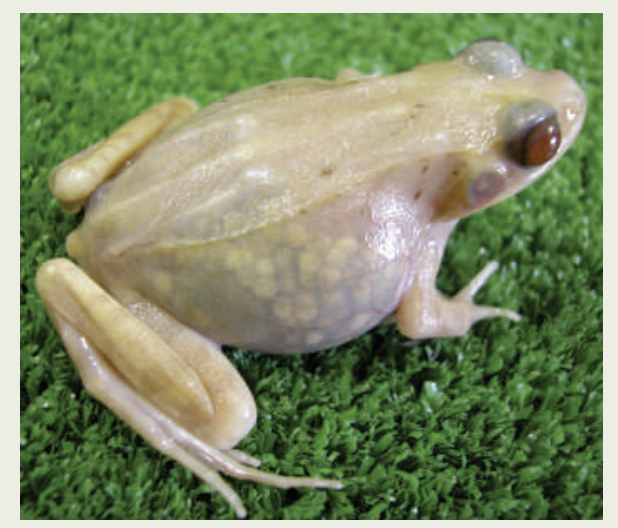

Who needs dissection when you can view a living frog in all its transparent glory?

Japanese biologists have created what they call the world's first see-through creature with four legs. (Some fish are naturally transparent.) The frogs started out as ordinary Japanese brown frogs (Rana japonica), but crossing animals with recessive genes for light-coloured skin led to transparency.

Internal organs, eggs and other normally concealed innards are all on full display in the new amphibian (pictured). Its creator, Masayuki Sumida of Hiroshima University, plans to seek a patent, according to the AFP news agency.

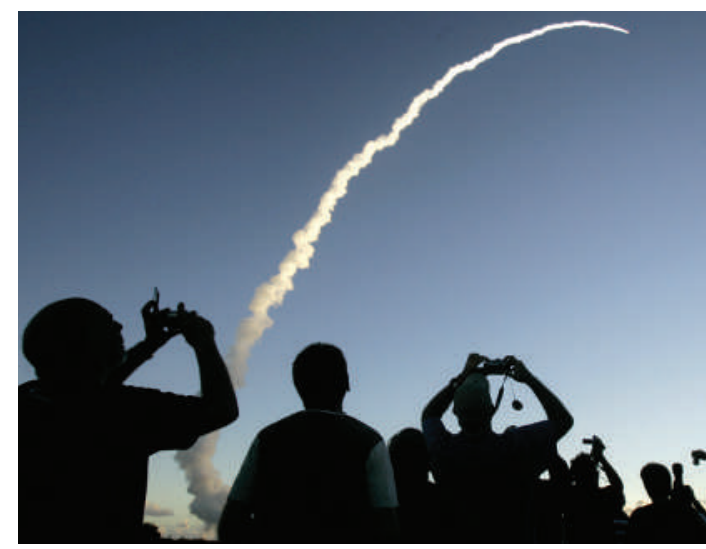

Up and away: NASA's Dawn probe takes off.

arrival of instruments through the Panama Canal. It had even been temporarily cancelled owing to cost overruns.

If Dawn had remained stuck during October, scientists would have had to wait 15 years for another launch window, says Carol Raymond, the mission's deputy principal investigator and a planetary scientist at the Jet Propulsion Laboratory in Pasadena, California. "It's obviously a tremendous feeling to finally see this mission get off the ground," she says.

After a 2.8-billion-kilometre journey, the probe will in 2011 reach Vesta, a highly reflective asteroid. In 2015, the spacecraft will rendezvous with Ceres - recently dubbed a dwarf planet. Dawn could confirm scientists' suspicions that Ceres hosts water and a thin atmosphere.

\section{Bird-flu virus can pass from mother to unborn child}

Chinese and US scientists have found for the first time that the H5N1 avian flu virus can pass across the placenta and infect unborn children.

The autopsies of a pregnant woman and a man, reported last week (J. Gu et al. Lancet 370, 1137-1145; 2007), also confirm that infection with the $\mathrm{H} 5 \mathrm{~N} 1$ virus affects multiple organs, and is not restricted to the respiratory system as is seasonal human flu.

Autopsies of $\mathrm{H} 5 \mathrm{~N} 1$ victims are rare, as corpses tend to be disposed of quickly. At least three reports, however, have shown that H5N1 infection in humans can affect the brain and multiple organs, which probably explains the high pathogenicity of the virus.

\footnotetext{
Correction

The News story 'Mystery ox finds its identity' (Nature 449, 124; 2007) stated that Gary Galbreath and his colleagues had concluded that the kouprey was a hybrid. In fact, they revised this conclusion in March 2007, determining that the ox was a distinct species, on the basis of fossil evidence (G. J. Galbreath, J. C. Mordaca and F. H. Weiler J. Zool. 271, 253-254; 2007).
} 